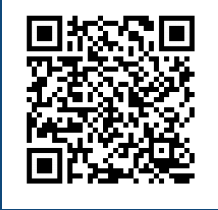

Keywords:

Less known woods

Mechanical resistance

Flooring standards

Historic:

Received 29/1 I/2018

Accepted 14/03/2019

+Correspondence: m.bezerradeoliveira@gmail.com
Mônica Bezerra de Oliveirala+, José Reinaldo Moreira da Silva'b ${ }^{1 b}$ Paulo Ricardo Gherardi Hein ${ }^{\text {lc }}$ José Tarcísio Limald

\section{ESTABLISHMENT OF QUALITY CLASSES FOR HARDWOOD FLOORINGS BY SIMULATED USE}

OLIVEIRA, M. B.; SILVA, J. R. M.; HEIN, P. R. G.; LIMA, J. T. Establishment of quality classes for hardwood floorings by simulated use. CERNE, v. 25, n. I, p. 105-109, 2019.

\section{HIGHLIGHTS}

The mechanical performance of wood floors were evaluated.

Denser woods presented highest mechanical strength.

A new table of mechanical performance classes was proposed.

Reference values can be used for predicting mechanical behaviour of wood floors of unknown species.

\section{ABSTRACT}

Many wood species have been employed as floorings, however their performance can vary greatly according to the wood properties and the type of application. Mechanical tests can be performed for simulating the wood floorings in service, but there are no standards for sorting the materials according to their quality as flooring. In this study, the tests carried out in commercial wood species to simulate the performance as flooring and propose a standard of classes resistance. Thus, the performance as wood flooring of Bowdichia nitida Benth (Spr.), Dipteryx odorata (aubl.) Willd, Mimosa scabrella Benth and Tabebuia impetiginosa in service were investigated. These commercial woods flooring were submitted to the falling ball, rolling load, floor surface indentation from small area loads and static and dynamic friction tests. The indentations caused were measured by micrometer coupled to a computer. According to the wood flooring performance in the simulation tests three resistance classes were established: high for indentations lower than $0.005 \mathrm{~mm}$ in floor surface indentation from small area loads, intermediate for depressions from 0.121 to $0.300 \mathrm{~mm}$ in rolling load test, and low for depressions higher than $0.30 \mathrm{I}$ in falling ball test. These classes can be used for predicting the performance, as wood flooring, of lesser known species. 


\section{INTRODUCTION}

The construction sector continues with yearly growth, which causes an increase in the consumption of wood floors in the market. According to the Brazilian Forest Industry - Ibá (20I8), the production of laminate flooring in 2017 totaled 11.9 million $\mathrm{m}^{2}$ in Brazil, the equivalent of a $2.0 \%$ increase compared to production in 2017. Despite the increase in consumption and the existing forest diversity, few wood species are used as flooring including cumaru, jatobá, peroba-rosa and ipê (Padilha et al., 2006).

According to Andrade et al. (2010) the increase in the consumption of wood floorings is important to improve product quality and increase competitiveness in the international market. As with other markets, companies that care about the quality of their products are prone to financial gains. However, company action regarding the standardization, quality and characterization of wood floorings are still scarce.

Therefore, to characterize the wood floors it is necessary to simulate their performance in service. For instance, some tests are carried out, such as the falling ball test, to simulates the performance when objects fall on the floor, rolling load test to simulate the dragging of heavy objects and indentation testing caused by loads applied in small areas to simulate heels trampling according to the procedures reported in D 2394-83 ASTM (1994) and finally static and dynamic friction tests.

Friction coefficient is the parameter for measuring the slip index. Higher friction values show floors to be less slippery and safer in order to avoid possible accidents. The dynamic coefficients of friction, measured on wet surfaces, are criteria for the classification of floors. Values less than or equal to 0.40 are satisfactory for normal installations. Values of 0.40 to 0.70 are recommended for slip resistance and greater than or equal to 0.70 for sites at risk of severe slip (NBR I38 I8-N, 1997).

These tests can be used to provide the consumer with information about the performance of the flooring industries, in addition to demonstrating the performance of the lesser known wood species.

Few studies have been conducted in order to evaluate the performance of species as wood flooring. Carmo (1996) evaluated the use of six different species of Eucalyptus and hardwoods (ipê, jatobá, cumaru and paraju) for floors. Padilha et al. (2006) and Santos et al. (2010) evaluated the potential of Eucalyptus urophylla in flooring applications, while Martins et al. (20I2) investigated the performance of Eucalyptus cloeziana and E. microcorys wood.
Todaro (2012) evaluated the effect of indirect steaming on the resistance to footprints of Quercus cerris L. wood for applications as parquet, and good elastic restoration was observed for untreated wood specimens, whereas for treated wood the resistance to footprints was higher in the radial than tangential direction.

Sepliarsky et al. (20/8) analyzed Eucalyptus globulus and Quercus robur (oak) with different bases (HDF, solid and plywood pine) using the falling ball impact test. Their results are independent of the species used (Eucalyptus or oak) as a noble layer, however, they depend on the type of element used a base. According to the authors, bases of high hardness, such as HDF, improve the resistance properties.

Currently, the D 2394-83 standard (ASTM, 1994) presents the tests and the details for conducting them. However, no standard values are presented to compare the mechanical performance among wood floorings from most of the wood species available in the flooring market.

The lack of these standards makes it difficult to characterize wood floorings for their proper uses and adequate instalation. Thus, the aim of this study was to simulate the use, in service, of these commercial and alternative wood species, in addition to propose resistance standard classes for the mechanical performance of wood flooring.

\section{MATERIAL AND METHODS}

Wood floorings of Bowdichia nitida Benth (Spr.) - Sucupira, Dipteryx odorata (aubl.) Willd - Cumaru, Mimosa scabrella Benth - Amendola and Tabebuia impetiginosa - Ipê were investigated. The wood floor samples were randomly selected in the production line of the Indusparquet company, located in Tietê city, São Paulo, Brazil.

\section{Preparation of material}

40 samples measuring $24 \times 14 \times 2 \mathrm{~cm}$ (length $\times$ width $x$ thickness) of each wood species were kept in an acclimatization chamber $\left(\mathrm{T}=20^{\circ} \mathrm{C} \pm 2{ }^{\circ} \mathrm{C}\right.$ and $\mathrm{RH}$ $=65 \% \pm 5 \%$ ) until reaching a $12 \%$ moisture content.

\section{Simulation tests of floors in service}

Static and dynamic friction tests, floor surface indentation from small area loads, rolling load and impact of falling ball tests were performed according to D 239483 (ASTM, 1994). Thus, the wood floor samples of the four species were placed randomly in the equipment, and the travel speeds used to perform the test was controlled by electric motors, as described by Santos et al. (20I0) and Martins et al. (20I2). 
Only the finished face of the samples was used for the tests. Two tests were performed on each sample. The first was the non-destructive static and dynamic friction test. The other destructive tests were then carried out, dividing the samples amont the three other tests (floor surface indentation from small area loads, rolling load and falling ball impact). Measurements of the depressions were obtained by a micrometer with 0.001 $\mathrm{mm}$ of precision.

\section{Statistical analyses}

Data were submitted to analysis of variance and when significant, the Scott-Knott test, at 5\% significance. In the falling ball test, the indentation index was calculated according to ASTM D 2394- 83 (ASTM, 1994).

\section{RESULTS AND DISCUSSION}

\section{Static and Dynamic Friction Test}

In the static friction test there was no significant difference among the averages of the different woods. The averages of the dynamic friction coefficient showed a significant difference and their values and are presented in Table I.

TABLE I Comparison of the static and dynamic friction coefficients of the wood species.

\begin{tabular}{|c|c|c|c|c|}
\hline \multirow{2}{*}{ Wood species } & \multirow{2}{*}{$\begin{array}{c}\text { Regional } \\
\text { name }\end{array}$} & \multirow{2}{*}{$\begin{array}{l}\text { Wood } \\
\text { density } \\
\left(\mathrm{g} \cdot \mathrm{cm}^{-3}\right)\end{array}$} & \multicolumn{2}{|c|}{ Friction test } \\
\hline & & & Static & Dynamic \\
\hline Tabebuia impetiginosa & Ipê & 1.067 & 0.269 & $0.198 \mathrm{a}$ \\
\hline Dipteryx odorata (aubl.) Willd & Cumaru & $\mathrm{I} .158$ & 0.253 & $0.175 \mathrm{~b}$ \\
\hline $\begin{array}{c}\text { Bowdichia nitida Benth (Spr.) } \\
\text { Mimosa scabrella Benth }\end{array}$ & $\begin{array}{l}\text { Sucupira } \\
\text { Amêndola }\end{array}$ & $\begin{array}{l}0.897 \\
0.621\end{array}$ & $\begin{array}{l}0.254 \\
0.265\end{array}$ & $\begin{array}{l}0.173 b \\
0.154 c\end{array}$ \\
\hline
\end{tabular}

In the Dynamic friction test, ipê wood showed the highest average while the amêndola had the lowest averages. Differently, the woods of cumaru and sucupira were statistically equal, although cumaru has $29 \%$ higher density than sucupira. According to NBR 13818-N (1997), all floors are indicated for normal installations.

Padilha et al. (2006) found, for Eucalyptus urophylla, values of static and dynamic friction coefficients around 0.38 and 0.23 , respectively. Martins et al. (2012), for Eucalyptus cléeziana and Eucalyptus microcorys, found static friction coefficient values of 0.25 and 0.28 , respectively. For the dynamic friction coefficients, 0.15 for Eucalyptus cloeziana and 0.13 for Eucalyptus microcorys were found.

Indentation test caused by loads applied in small areas

In the test of indentation caused by loads applied in small areas, the cumaru and ipê woods did not present depressions after 100 runs; the observed damage was only grooves in the lacquer film. This result may have occurred due to the hardness of these woods, which are classified as very heavy (MAINIERI; CHIMELO, 1989), with densities of 1.09 and $\mathrm{I} .0 \mathrm{I} \mathrm{g} \cdot \mathrm{cm}^{-3}$ for cumaru and ipê, respectively. These high densities provided higher strength and hardness, which reflected in the applied load resistance. The results indicate these two woods have potential for use in places of intense traffic, such as restaurants, malls and banks.

The mean indentation values for the sucupira and amêndola woods were 0.016 and $0.024 \mathrm{~mm}$, respectively, for 100 runs. For not presenting a statistical difference the amêndola behaved in a similar way to sucupira, a species used commercially (Associação Nacional dos produtores de pisos de madeira - ANPM, 20I I), thus indicating the marketing potential of the amêndola.

Padilha et al. (2006) found indentation values for Eucalyptus urophylla wood, between 0.049 and 0.092 $\mathrm{mm}$. Martins et al. (20/2), for Eucalyptus microcorys, found values of $0.050 \mathrm{~mm}$.

Rolling Load Test

For all groups runs $\left(10^{\text {th }}, 25^{\text {th }}\right.$ or $\left.50^{\text {th }}\right)$ in the rolling load test the mean depressions for ipê, cumaru and sucupira were considered statistically equal, differing from the amêndola wood (Figure I).

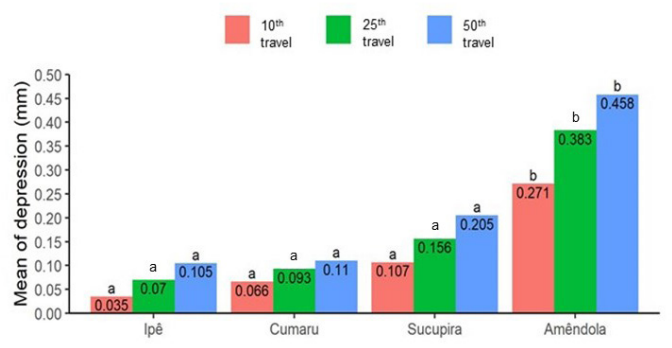

FIGURE I Comparison of mean values of depressions caused during the rolling load test in the $10^{\text {th }}, 25^{\text {th }}$ and $50^{\text {th }}$ trips among wood species. For the same trip number, averages followed by at least one same letter do not differ by $5 \%$ significance by the Scott-Knott test.

The lowest depression value found was for ipê and the highest for the amêndola, which have densities of 1.067 and $0.62 \mathrm{Ig} \cdot \mathrm{cm}^{-3}$, respectively. It is important to note that the higher the depression, the lower the wood density and consequently the mechanical strength of the wood, Therefore, the amêndola is not indicated for places with constant dragging of objects.

The mean of the depressions found by Martins et al. (2012) in Eucalyptus microcorys and Eucalyptus cloeziana wood were 0.154 and $0.190 \mathrm{~mm}$, respectively. Carmo (1996) found depression values for the rolling 
load of 1.03 and $0.83 \mathrm{~mm}$ for cumaru and ipê woods, respectively. Santos et al. (20I0), for Eucalyptus urophylla wood, found values under $0.47 \mathrm{Im}$ for the same property.

Falling ball impact test

The mean values of depressions found in the falling ball impact test and indentation index of the wood are shown in Table 2.

TABLE 2 Comparison of the mean values of the depressions obtained in the falling ball impact test.

\begin{tabular}{ccc}
\hline Regional name & $\begin{array}{c}\text { Mean of depressions } \\
(\mathrm{mm})\end{array}$ & Indentation Index \\
\hline Cumaru & $0.129 \mathrm{a}$ & 0.186 \\
Ipê & $0.159 \mathrm{a}$ & 0.241 \\
Sucupira & $0.262 \mathrm{~b}$ & 0.390 \\
Amêndola & $0.358 \mathrm{c}$ & 0.537 \\
\hline
\end{tabular}

Means followed by at least one letter vertically do not differ from each other a $5 \%$ significance by the Scott-Knott test.

The results indicate a relationship between the values of depressions and the density of the material. The highest indentation value $(0.358 \mathrm{~mm})$ was for amêndola wood, which has the lowest density value $\left(0.621 \mathrm{~g} \cdot \mathrm{cm}^{-3}\right)$ compared to the other woods, while cumaru with, I.I58 $\mathrm{g} \cdot \mathrm{cm}^{-3}$ of density showed the lowest depression, $0.129 \mathrm{~mm}$.

The indentation index indicates that, the lower its value, the higher the resistance of the wood floor to the depression that falling objects may cause. Therefore, the cumaru wood has the highest resistance among the studied woods.

Padilha et al. (2006) found, for Eucalyptus urophylla, values of $0.493 \mathrm{~mm}$ for mean depression of the falling ball test. Moreover, Carmo (1996) found 0.530 $\mathrm{mm} ; 0.330 \mathrm{~mm}$ and $0.320 \mathrm{~mm}$ for the wood depressions in Eucalyptus urophylla, cumaru and ipê, respectively, in the same test.

\section{Resistance Classes}

Table 3 shows the limit values of the quality classes for floorings of different woods, which were established as a function of the depressions analyzed. These classes can be used as comparison indices with other woods.

TABLE 3 Indices for determining the quality classes of wood flooring.

\begin{tabular}{cccc}
\hline \multirow{2}{*}{ Test } & \multicolumn{3}{c}{ Floor quality classes } \\
\cline { 2 - 4 } & High & Intermediate & Low \\
\hline Static and & Greater than & From $0.16 \mathrm{I}$ to & Less than \\
dynamic friction & $0.18 \mathrm{I}$ & 0.180 & $0.18 \mathrm{I}$ \\
Applied load & Less than & From 0.006 to & Greater than \\
$(\mathrm{mm})$ & 0.005 & 0.030 & $0.03 \mathrm{I}$ \\
Rolling load & Less than & From $0.12 \mathrm{I}$ to & Greater than \\
(mm) & 0.120 & 0.300 & $0.30 \mathrm{I}$ \\
Falling ball & Less than & From $0.18 \mathrm{I}$ to & Greater than \\
$(\mathrm{mm})$ & 0.180 & 0.300 & $0.30 \mathrm{I}$ \\
\hline
\end{tabular}

By averages of the results obtained in each test and comparison with the literature on different woods, it was possible to define quality classes regarding the simulation of flooring under use as such, it is possible to indicate which floor is suited to be installed in a given place. Environments with high traffic, with dragged or falling objects, like industries, are indicated to use flooring of intermediate and high resistance.

The wood flooring mechanical performance classes proposed in Table 3 offer technical information for companies that produce wood floors, to provide specifications to their consumers about the resistance of their products under use.

\section{CONCLUSION}

The highest mechanical strength in the indentation test caused by loads applied in small areas was obtained for ipê and the lowest indentation indices in the falling ball test were obtained for cumaru woods

The highest dynamic friction coefficient was found for ipê wood, whereas the lowest indentation value in the rolling load test was observed in cumaru wood samples.

The classes of mechanical performance of wood floors proposed in this study can be used as a reference for comparisons of performance of unknown wood species with the same features in internal flooring applications, providing useful information to the consumer.

\section{REFERENCES}

AMERICAN SOCIETY FOR TESTING AND MATERIALS. ASTM D 2394-83. Philadephia, 1994. 608p.

ANDRADE, A.; JANKOWSKY, I. P.; TAKESHITA, S.; NETO VIEIRA, P. R. Análise de qualidade em pisos de madeira. Revista da Madeira - n.125, p.I2-18, 2010.

ASSOCIAÇÃO BRASILEIRA DE NORMAS TECNICAS. ABNT NBR I38I8: 1997 - "Placas para Cerâmicas para Revestimento- Especificação e Métodos de Ensaio”; Abril/I997. 78p.

ASSOCIAÇÃO NACIONAL DOS PRODUTORES DE PISOS DE MADEIRA - ANMP. Associação Nacional dos Produtores de Pisos de Madeiras. Análise tecnológica e econômica do setor brasileiro de pisos de madeira. Piracicaba, 20II. 69 p.

CARMO, A. P. T. Avaliação de algumas propriedades da madeira de seis espécies de eucalipto. 1996. 74 p. Dissertação (Mestrado em Ciências Florestais) Universidade Federal de Viçosa, Viçosa, MG, 1996.

INDUSTRIA BRASILEIRA DE ÁRVORES - Ibá. Dados do Relatório 2018, ano base 2017, Brasília, 2018, 6p. 
MAINIERI, C.; CHIMELO, J. P. Fichas de características das madeiras brasileiras. 2. ed. São Paulo: Instituto de Pesquisas Tecnológicas do Estado de São Paulo, 1989. 419 p.

MARTINS, M.; SILVA, J. R. M.; LIMA, J. T.; GONÇALVEZ, M. T. T.; FILIPE, A. P. Simulação em uso dos pisos de madeira de Eucalyptus sp e Corymbia maculata. Cerne, Lavras, v. 19, n. I, p. I5I-I56, 2012.

PADILHA, C.; LIMA, J. T.; SILVA, J. R. M; TRUGILHO, P. F; ANDRADE, H. B. Avaliação da qualidade da madeira de Eucalyptus urophylla para utilização em pisos. Scientia Forestalis, Piracicaba, v. 2, n. 7I, p. |4|-|47, ago. 2006.
SANTOS, I. S.; LIMA, J. T.; SILVA, J. R. M. Avaliação de pisos produzidos a partir de toras de clones de Eucalyptus sp. com pequenos diâmetros. Cerne, Lavras, v. 16, n. 4, p. 473-478, 2010.

SEPLIARSKY, F.; MARTIN, R. T.; RELLO, L.A. Parquet Multicapa de Eucalyptus globulus y Quercus robur. Resistencia al Impacto para diversas tipologias de fabricación. Maderas. Ciencia y tecnologia, v.20, n. I, p. 10 - II6, 2018.

TODARO, L. Effect of steaming treatment on resistance to footprints in Turkey oak wood for flooring. European Journal of Wood and Wood Products. v.70, n.(I-3), p.209-2|4, 2012. 